\title{
Carbon Dioxide Emissions, Energy Consumption and Economic Growth: A Comparative Empirical Study of Selected Developed and Developing Countries. "The Role of Exergy"
}

\author{
Raúl Arango-Miranda ${ }^{1, *} * \mathbb{D}$, Robert Hausler ${ }^{1,+}$, Rabindranarth Romero-Lopez ${ }^{2,+}$, \\ Mathias Glaus ${ }^{1,+}$ and Sara P. Ibarra-Zavaleta ${ }^{3,+}$ \\ 1 Station Expérimentale des Procédés Pilotes en Environnement, École de Technologie Supérieure, \\ Université du Québec, 1100, rue Notre-Dame Ouest Local A-1500, Montréal, QC H3C 1K3, Canada; \\ robert.hausler@etsmtl.ca (R.H.); mathias.glaus@etsmtl.ca (M.G.) \\ 2 Unidad de Investigación Especializada en Hidroinformática y Tecnología Ambiental, Facultad de Ingeniería \\ Civil, Universidad Veracruzana, Lomas del Estadio s/n, Zona Universitaria, Xalapa 91090, Veracruz, Mexico; \\ rabromero@uv.mx \\ 3 Instituto de Biotecnología y Ecología Aplicada, Universidad Veracruzana, Av. de las Culturas Núm.101, \\ Col. Emiliano Zapata, Xalapa 91000, Veracruz, Mexico; saibarra@uv.mx \\ * Correspondence: raul.arango-miranda.1@ens.etsmtl.ca; Tel.: +1-514-396-8800 (ext. 7686) \\ + These authors contributed equally to this work.
}

Received: 5 September 2018; Accepted: 1 October 2018; Published: 7 October 2018

\begin{abstract}
Diverse factors may have an impact in carbon dioxide $\left(\mathrm{CO}_{2}\right)$ emissions; thus, three main contributors, energy consumption, gross domestic product (GDP) and an exergy indicator are examined in this work. This study explores the relationship between economic growth and energy consumption by means of the hypothesis postulated for the Environmental Kuznets Curve (EKC). Panel data for ten countries, from 1971 to 2014 have been studied. Despite a wide gamma of research on the EKC, the role of an exergy variable has not been tested to find the EKC; for this reason, exergy analysis is proposed. Exergy analyses were performed to propose an exergetic indicator as a control variable and a comparative empirical study is developed to study a multivariable framework with the aim to detect correlations between them. High correlation between $\mathrm{CO}_{2}, \mathrm{GDP}$, energy consumption, energy intensity and trade openness are observed, on the other hand not statistically significant values for trade openness and energy intensity. The results do not support the EKC hypothesis, however exergy intensity opens the door for future research once it proves to be a useful control variable. Exergy provides opportunities to analyze and implement energy and environmental policies in these countries, with the possibility to link exergy efficiencies and the use of renewables.
\end{abstract}

Keywords: climate change; energy policy; exergy analysis; exergetic intensity; greenhouse gases

\section{Introduction}

The growing consumption trends of modern societies increase the pressure on manufacturing to satisfy such demands [1]. The growing request of fossil fuels as the main source of energy is triggering environmental degradation, that is without a doubt, one of the most pressing global atmospheric challenges experienced by developed and developing countries in 21st century in the form of greenhouse gases (GHG), global warming (GW) and climate change (CC) [2]. In this growing trend of economies, over the past few decades, countries were transitioning from agriculture to 
manufacturing or even service-based economies in the case of Asian countries [3]. Low carbon energy transitions are important to mitigate climate change, reduce air pollution, and reduce fossil fuel resource depletion [4]. Once natural resources are not infinite as a source for economic activities, then uncontrolled economic development entails actual risks for the global environment [5]. Energy is an indispensable input in the economic activity process. Since the effects of openness and economic reforms, China among other developing countries has become the fastest growing countries in the world, impulsed by rapidly increasing energy consumption [6]. The rates of worldwide economic development indicate that increased energy demand at all sectoral levels may represent a threat to the achievement of global reduction objectives for 2050 [7]. Rapid global economic growth between 2005 and 2013, influenced global GHG emissions increased by $18.3 \%$ reaching more than 35 billion tons by 2013 [8]. According to the Intergovernmental Panel on Climate Change (IPCC), the combustion of fossil fuels unavoidably produces GHGs, comprising mainly $\mathrm{CO}_{2}$, among others [7]. Virtually $90 \%$ of the $\mathrm{CO}_{2}$ emissions has a fossil-fuel source and therefore are determined by the energy demand or the level of energy-intensive activity. After several periods of economic growth without considering environmental damage, academics, practitioners and policy makers, mostly representing developed countries perceiving the risk related with industrialization and deforestation processes, among other anthropogenic activities and react; hence, a heated debate between the importance of economy without compromising our natural resources started [9]. How to tackle the problem of climate change is a great challenge. Sustainability offers an approach to combat GHG and CC. In late 80's, efforts from governmental and non-governmental organizations mainly in industrialized countries, were the first steps in the route of sustainable development [10]. To control the carbon emissions issues, governments have been taken actions to face this challenge [11]. As part of this effort, at industrial level the $\mathrm{CO}_{2}$ emissions are broadly used to represent the environmental performance of a firm [12]. In 1992, Munasinghe introduced three major poles to the definition of sustainability: economic, social, and environmental [13]. In the use of different approaches to address the challenges of sustainability, Ponta [14] proposed the use of agent based macroeconomic models to analyze energy policies to foster the sustainability transition. In the same filed, Wolf [15] analyzed the benefits of different computational models and their benefits as tools to help decision makers regarding the relation between climate change and growth.

However, due its complexity, only a limited number of studies had tested the three axes of sustainability and the interrelationship of its variables in the same framework [16,17]. The idea of causal relationship between energy consumption and economic growth was first introduced in the influential paper of Kraft [18], once the causality relationship between them has important policy implications. The debate about what becomes first, economics or environment, no matter at local or global level was settled and the functional relationships between economic growth and environmental degradation were masterfully expressed by the Environmental Kuznets Curve (EKC), an inverted U-shape curve [19]. This dilemma about economic activity and pollution opened up paths for a rich research agenda [20]. A literature review on the EKC starts with the seminal research from Grossman and Krueger [21] in their attempt to explore the path of sustainable development theory to describe the environmental degradation-economic growth relationship. Then, many scholars have been developed empirical studies of the EKC hypothesis in single or multiple countries, even regions, applying different econometric methodologies [19,22-24]. Other researches have focused their attention for different environmental dimensions (i.e., $\mathrm{CO}_{2}, \mathrm{SO}_{2}$, particulate matter, waste water, protected areas) or time contexts. Mixed and even inconclusive findings are still reported [25]. Scholars found that the relationship presented multiple shaped EKC such as U, inverted-U, N, etc. Additionally, there were also evidences that the testing results depended on the specific econometric models [26]. Several authors have reviewed and summarized the vast literature of the EKC, the contributions of Kaika among others [24,27-29] offers an overview of the relevant past empirical studies.

Despite all this wide gamma of research, the role of an exergy variable has not been tested to find the EKC, then exergy analysis is proposed with the goal to enrich sustainability and exergy as 
elements of environmental studies, once exergy links thermodynamic principles and system under study with the environment [30]. Loiseau [31] compared environmental assessment tools and methods and quotes that among others, exergy analysis are part of the "energy family of methodologies" applying thermodynamics to sustainability able to study cities or industries [32-34].

Exergy has been evolved by years, as showed by Sciubba [35] in his essential brief commented history on exergy. From the theoretical concepts from Carnot and Gibbs, the research by Reistad [36], as a notion to resource accounting approaches by Wall [37,38], the efficiency improvements in industrial equipment or power cycles and its components [39], complex systems analysis [40], sectors and extended exergy analysis in societies or countries [41-44]. To the more recently link to the environment studied by Dincer and Rosen [45] in their comprehensive Exergy: energy, environment and sustainable development. The conducted studies on exergy analysis of the industrial sector are classified into three main subsections: countries; industrial subsectors or industrial activities; and industrial devices [46]. Romero in his review of the state of the art indicators for sustainability, claims the suitability of using exergy as an indicator for energy sustainability studies, also exergy can serve as a link to fill gaps in the generation of economic and environmental indicators [47]. Gong established that "to improve energy and material conversion processes, the exergy concept should be applied. Therefore, exergy analysis is a tool to create and maintain a sustainable or rather a vital society" [48]. Researchers also claim that exergy brings opportunities in decision-making to increase energy efficiency and energy conservation [49]. In parallel, exergy analysis was also studied regarding the environment and sustainability [50,51]. It may be reported that to the best of authors' knowledge, there is no work on the review of exergy analysis and the $\mathrm{CO}_{2}$ emissions involving the EKC theory regarding the industrial sector. This research is expected to contribute to fill this gap. The aim of this work is to examine correlations between economic growth, energy consumption and $\mathrm{CO}_{2}$ emissions. We use a data panel of ten countries from 1971 to 2014 to examine relationships between energy consumption and economic growth. First, we examine these variables using a simplest specification of the EKC hypothesis, a linear equation with aim to test the influence of an exergy indicator as a control variable and its effects. Second, a panel fully modified ordinary least squares method is used to test the significance of the model. Similar to previous studies, we find that the two variables are both integrated of order one. The rest of the paper is organized as follows: Section 2 describes the data that is used in the empirical research. Section 3 displays the exergy analysis and the econometric methodologies. Section 4 presents empirical results and the interpretations. Section 5 concludes the paper with some policy implications.

\section{Data Sources}

In this study, yearly data of GDP (in constant 2005 US dollars) and energy consumption (million tons oil equivalent) is revised for a set of ten countries (a mix of five developed and five developing countries, includes: Brazil, Canada, China, Italy, Mexico, Norway, South Africa, Turkey, UK and USA) to investigate the relationship between $\mathrm{CO}_{2}$ emissions, energy consumption and economic growth. Data from the IEA database [52] and the report " $\mathrm{CO}_{2}$ Emissions from Fuel Combustion, IEA 2017" [53], was achieved and analyzed chronologically from 1971 to 2014. The temporal dimension was restricted due to data availability.

\subsection{Countries Selection Criteria}

\subsubsection{Socioeconomic Criteria}

According to the World Bank to pay attention to the economical-social-environmental challenges of the future, the upper-middle income countries, whose industrialization process increased strongly, need to be assessed deeply [54]. The idea to contrast two sets of countries is based on the socio economic and environmental changes through last four decades. The selected sample consists of a mixture of developed and developing countries. Between them, there are similarities: economic growth, geographical, population and the production of manufacturing goods to exports. Another interesting 
factor is that usually, some developing countries evolved from an economic base of agriculture towards manufacturing [55]. Agreeing their economic and social development, a key factor in terms of data availability was that most of them share an association with two international institutions: The Organization for Development and Economic Cooperation (OECD); and the International Energy Agency (IEA). Additionally, nine out of ten countries are part of the G20 countries.

\subsubsection{Environmental Criteria}

Four of them were listed as the world's major GHG emitters [56]. The Climate Change Performance Index (CCPI) 2014 report [53,57] assesses and compare the climate protection performance of 58 countries, that are, jointly, responsible for more than 90 percent of global energy-related $\mathrm{CO}_{2}$ emissions, the results for the selected countries were the following: Canada and Turkey received a "very poor rank", the 58th and 54th; China, United States, South Africa, Brazil received a "poor" rank, the 46th, 43rd, 39th and 36th; Norway, Mexico and Italy received a "moderate" rank, the 24th, 20th and 18th; while the United Kingdom received a "good" rank, the 5th. Table 1 shows the trends of change on the environmental variable, carbon dioxide emissions, between the years 1971 to 2014. It reveals the difference among the ten countries in terms of $\mathrm{CO}_{2}$ emissions, highlighting the previously cited ranks.

Table 1. Environmental variable, comparison of variations coefficients from the year 1971 to 2014.

\begin{tabular}{|c|c|c|c|c|c|c|}
\hline & 1971 & 2014 & & \multirow{3}{*}{ Mean } & \multirow{3}{*}{$\begin{array}{l}\text { Standard } \\
\text { Error }\end{array}$} & \multirow{3}{*}{$\mathrm{CV}$} \\
\hline Country & $\begin{array}{c}\mathrm{ffCO}_{2} \\
\text { Emissions }\end{array}$ & $\begin{array}{c}\mathrm{ffCO}_{2} \\
\text { Emissions }\end{array}$ & \multirow{2}{*}{$\begin{array}{l}\text { Rate of } \\
\text { Growth }\end{array}$} & & & \\
\hline Units & Mton/year & Mton/year & & & & \\
\hline Mexico & 93.7 & 430.9 & 4.6 & 291.1 & 238.4 & 0.82 \\
\hline Canada & 340.1 & 554.8 & 1.6 & 453.2 & 151.8 & 0.33 \\
\hline USA & 4288.1 & 5176.2 & 1.2 & 4987.8 & 628.0 & 0.13 \\
\hline Italy & 289.3 & 319.7 & 1.1 & 375.9 & 21.5 & 0.06 \\
\hline Norway & 23.0 & 35.3 & 1.5 & 30.2 & 8.7 & 0.29 \\
\hline United Kingdom & 621.0 & 407.8 & 0.7 & 537.0 & 150.7 & 0.28 \\
\hline China & 789.4 & 9134.9 & 11.6 & 3323.6 & 5901.2 & 1.78 \\
\hline South Africa & 157.1 & 437.4 & 2.8 & 277.3 & 198.2 & 0.71 \\
\hline Turkey & 41.7 & 307.1 & 7.4 & 151.4 & 187.7 & 1.24 \\
\hline Brazil & 87.5 & 476.0 & 5.4 & 234.5 & 274.8 & 1.17 \\
\hline
\end{tabular}

\section{Methods}

This study analyzes the relationship between carbon dioxide emissions, energy consumption and economic growth, with addition of an exergetic control variable to test the EKC hypothesis. First we describe the exergy analysis methods. Followed by a descriptive statistical analysis based on a statistical generalized linear model (GLM). Last, an econometric analysis including an ordinary least squares analysis. The three steps are described below:

1. Exergy Analyses to Compute Exergy Consumption and Exergy Intensity

2. A Descriptive Statistical Analysis to Detect Linear Correlations (R) between the Variables

3. An Econometric Analysis, Including an Ordinary Least Squares Analysis (OLS)

A data set of 440 observations is considered in this research. The carbon dioxide emissions per capita $\left(\mathrm{CO}_{2} /\right.$ Capita) measured in metric tons per person was considered as the environmental decline variable. The growth variable is estimated by the per capita GDP, measured in United States dollars at 2005 prices. Since exergy can serve as a link to fill gaps in the generation of economic and environmental indicators, to serve as control variables, two exergetic variables were computed: exergetic consumption and exergetic intensity. In a global economy, the selected ten countries have been increasing their economic or commercial trade; accordingly, the specific impact of trade was 
analyzed through the trade openness variable. The list of abbreviations and meanings of the variables utilized in this study is presented before the references.

\subsection{Exergy Analysis Theoretical Background}

An energy and exergy analysis of the selected ten countries was carried out, from the period 1971-2014; the energy intensities were taken from the IEA databases, to compute the exergy intensities. This is a key part of the innovative approach of this study in the search for the EKC hypothesis; which consists of proposing exergetic indicators as control variables.

Scholars have been studying exergy analysis on a large-scale base, such as a country, its society or their own economic sectors [43,58]. In 1997, Dincer [59] assessed the energy consumption of the industrial sector in Canada to increase its efficiency based on exergetic analyses. To formulate an exergy balance of a non-constant flow system (like mass or energy balances), a common scenario requires establishing a control volume as well as a reference environment; it is usually established through a temperature $T_{0}=25^{\circ} \mathrm{C}$ and a $P_{0}=1 \mathrm{~atm}$ [44]. The flow of exergy entering in a system can be best described as the sum of the totality of their exergies (physical, chemical, potential, kinetic and nuclear exergies) [60]:

$$
\text { Exergy }_{\text {sys }}=\text { Exergy }^{P h}+\text { Exergy }^{K n}+\text { Exergy }^{P t}+\text { Exergy }^{C h}+\cdots
$$

\subsubsection{Exergy of a Flowing Stream of Matter}

In principle, the exergy of matter can be determined by letting it be brought to the dead state by means of reversible processes. The basic formulas used in exergy analysis modeling are given below. The total exergy can be divided into two-parts: physical exergy (thermo-mechanical exergy) and chemical exergy. The specific total exergy of the flowing stream of matter can be expressed as:

$$
\text { Exergy }=\text { Exergy }^{P h}+\text { Exergy }^{C h}
$$

The first part of Equation (1) represents the physical exergy, while the second represents the chemical exergy. The physical exergy is the maximum work obtainable by taking the matter through reversible processes from its initial state (temperature: $T$ and pressure: $P$ ) to the state determined by the environment conditions (temperature: $T_{o}$ and pressure: $P_{o}$ ). The chemical exergy is the maximum work that can be obtained by taking a substance having the parameters $\left(\mathrm{To}_{0} \mathrm{Po}_{\mathrm{o}} \mathrm{mjo}\right)$ to the state determined by the dead state $\left(T_{0}, P_{0}, m j_{0}\right)$.

\subsubsection{Exergy of Fuels}

On industry, the most common mass flows are hydrocarbon fuels at near-ambient conditions; then the term Exergy ${ }^{P h}$ in Equation (2) is approximately zero, as a result the exergy reduces to chemical exergy $\left(\right.$ Exergy $\left.^{C h}\right)$; next it can be written as ([44,61-63]:

$$
\text { Exergy }=\gamma_{f} H H V_{f}
$$

where $\gamma f$ denotes the exergy grade function or exergy factor of the fuel, defined as the ratio of chemical exergy to the higher heating value (HHVf). With the use of the exergy factor, conversions of energy data to exergy values of energy carriers are given by a proportionality constant [63,64]. In other words, due the complexity of the chemical composition of fuels, a simple approach was applied, since the higher heating value $(H H V f)$ is close to the chemical exergy. In this paper, the average exergy grade functions for different energy carriers are considered, extracted of several sources [43,44,49]. There are also other fuels obtained as by products from the different processes in the manufacturing sector. 


\subsection{Linear Correlations Coefficients(R) Detection}

First, in a set of 44 observations, the annual averages are calculated by country for each variable, proceeding to estimate the correlations based on the variable $\mathrm{pcCO}_{2}$. Secondly, the complete data were analyzed, by year and by country (440 observations) in function of $\mathrm{pcCO}_{2}$.

Subsequently, a descriptive statistical analysis is developed, based on empirical tests, with the aim of detecting the strength and direction of a linear relationship and proportionality between two study variables, by means of linear correlation $(R)$ among the proposed variables. Table 2 describes the total set of variables applied in this study in search of the existence of the EKC.

Table 2. Multivariable framework summary [65].

\begin{tabular}{cccc}
\hline No. & Abbreviation & Description & Units \\
\hline 1 & $\mathrm{pcCO}_{2}$ & $\mathrm{CO}_{2}$ Emissions & $\mathrm{Mt} \mathrm{of} \mathrm{CO}_{2} /$ year/Capita \\
2 & $\mathrm{ffCO}_{2}$ & $\mathrm{CO}_{2}$ Emissions from Fossil Fuels & Mton/year \\
3 & $\mathrm{pcTPES}$ & Total Primary Energy Supply & toe/Capita \\
4 & $\mathrm{pcGDP}$ & GDP per capita; USD 2005 & Billion USD, 2005 \\
5 & Tr opn & Trade openness & $\%$ \\
6 & ffEn con & Energy consumption from Fossil Fuels & $\mathrm{PJ} /$ year \\
7 & En int & Energy Intensity & $\mathrm{TPES} / \mathrm{GDP}$ \\
8 & $\mathrm{C}$ int & Carbon intensity & Mton/year \\
9 & Ex con & Exergy Consumption & PJ/year \\
10 & Ex int & Exergy Intensity & $\mathrm{TPES} / \mathrm{GDP}$ \\
\hline
\end{tabular}

Prior to the econometric analysis, the data sets were are analyzed and the moderate correlation coefficients $(-0.5<R)$ and $(R>0.5)$ were identified [66].

\subsection{Econometric Analysis}

To test the existence of the EKC hypothesis, a model using panel data estimation techniques was developed. The approach on this research adjusts to the simplest specification of EKC hypothesis, a linear equation, with the aim to test the viability of exergy indicators and its possible effects. Additionally, to test the significance of the model, an ordinary least squares analysis (OLS) was developed.

The EKC literature refers there are four main hypotheses to explain the direction of the relationship between energy consumption and economic growth: growth, conservation, feedback and neutrality $[23,67]$. The growth hypothesis validates a unidirectional causality flowing from energy consumption to economic growth. The conservation hypothesis argues that there is a one-way causality flowing from economic growth to energy consumption. The feedback hypothesis validates that energy consumption and economic growth cause each other. The neutrality hypothesis contents that there is no causality flowing between economic growth and energy consumption. According to Grossman and Krueger, Panayotou, De Bruyn, Dinda, among others, the generalized functional form of the equation to test the EKC is presented as follow $[21,22,68,69]$ :

$$
E D=f\left(E G_{i t}, E n C_{i t}, E x C_{i t}, \operatorname{Tr} O_{i t}, \mu_{i t}\right)
$$

where $E D=$ Environmental degradation $=\mathrm{ffCO}_{2} ; E G=$ Economic Growth = pcGDP; $E n C=$ Energy consumption $=$ En con; $E x C=$ Exergy consumption $=$ Ex con; $\operatorname{Tr} O=$ Trade openness $=\operatorname{Tr}$ opn and $\mu_{i, t}=$ error term. The Environmental Kuznets Curve for lineal model can be written as follows:

$$
\mathrm{CO}_{2 t}=\beta_{0 i t}+\beta_{1 i t} * G D P+\mu_{i t}
$$


In this research, an extended form of the model, used to investigate the influence of an exergetic variable on the environment, can be described as follows:

$$
f f C O_{2}=\beta_{1} * G D P+\beta_{2} * f f E n c o n+\beta_{3} * E x c o n+\beta_{4} * \text { Exint }+\beta_{5} * p c T P E S+\beta_{6} * \text { Tr opn }
$$

\section{Results and Discussion}

\subsection{Energy and Exergy Analysis}

This section discusses the measurement concept of exergy indicators, presents the new data set, and clarifies the relationship between energy losses and exergy indicators. Energy and exergy analysis were developed to calculate exergetic variables from a selected panel of ten countries, from 1971 to 2014 .

Starting with the compute of the energy and exergy inputs by selected countries, Table 3 shows the results of exergy input consumption (PJ) as an example for the year 2014; energy carriers were considered, with fossil fuels largely highlighting as the main source for most of the countries and along the 44 years spanned.

Table 3. Exergy consumption rates of countries, year 2014.

\begin{tabular}{ccccccc}
\hline \multicolumn{7}{c}{ Energy Carriers (Ktoe) } \\
\hline Country & Hydrocarbons & Renewables & Nuclear & Electricity & Heat & $\begin{array}{c}\text { Total Exergy } \\
\text { Consumptions (PJ) }\end{array}$ \\
\hline Mexico & 173,077 & 16,989 & 2446 & 45 & 0 & 8060 \\
Canada & 208,128 & 51,229 & 27,119 & 3923 & 0 & 12,597 \\
USA & $1,878,318$ & 167,673 & 209,961 & 4576 & 0 & 99,790 \\
Italy & 116,650 & 29,163 & 0 & 3760 & 0 & 6829 \\
Norway & 15,508 & 13,489 & 0 & 1340 & 59 & 1771 \\
United Kingdom & 151,000 & 14,433 & 16,115 & 1765 & 0 & 7974 \\
Turkey & 112,122 & 12,390 & 0 & 452 & 0 & 5213 \\
China & $2,819,883$ & 259,014 & 33,504 & 202 & 0 & 131,083 \\
South Africa & 132,893 & 18,187 & 3487 & 229 & 0 & 6471 \\
Brazil & 183,308 & 129,313 & 3888 & 2905 & 44 & 13,375 \\
\hline
\end{tabular}

Table 3 contains interesting information; first the use of fossil fuels still has a strong tendency to increase along the 44 years observed in the ten countries; highlights that hydrocarbons are the main energy carrier with rates from $47 \%$ to $90 \%$, despite remarkable consumption rates of natural gas near 30\%. Shahbaz found that coal consumption significantly deteriorates environmental quality. Particularly, Data shows that coal plays a key role in China and South Africa; both countries have important coal reserves, just South Africa owned 3.68\% of the world coal reserves by 2009 [70]. The primary energy needs in both countries is based in Coal, near 70\% by 2015 [71]. Renewable fuels are employed with higher rates than $10 \%$ in six of ten countries, highlighting Norway with a highest 48\%, followed by Brazil with 39\%. According to the IEA, China, USA, Canada, UK, Brazil, Turkey, Italy and Mexico are listed among the worldwide major producers of iron, steel and cement [72]. The most important topic in exergy analysis is the second law efficiency. Due to continuous increases in the energy price in the last forty years, engineers tend to utilize thermal systems or components that have maximum second law efficiencies, in industrial processes or devices. In this way, they can be confident is the best way to use the energy source thus, minimizing the expenditures.

In parallel, energy security is an essential ingredient to development. Therefore, increasing energy consumption may be one of the fundamental aspirations of developing regions such as Latin American, Asian and African countries [66,73]. Paired with energy increasing to satisfy societal demands, another key factor to boost energy security is minimizing energy lost or degradations in the form of inefficiencies. Hereafter, it is important to create datasets of exergy indicators to improve energy efficiencies, consequently to strong energy security. 
Degradation of energy matters because it might be a consequence of process inefficiency or environmental impact producing materials, i.e., GHG [35,48,49]. According with Hepbasli [74], exergy is concerned with the quality of energy to cause change, degradation of energy during a process, entropy generation and the lost opportunities to do work. Then exergy is a fitted tool to improve efficiencies in manufacturing. According to Rosen exergy is a measure of environmental degradation, consequently a tool to minimize environmental harm. Then, exergy is a key component to sustainability. Moreover, exergy indicators are essential to distinguish the quality between energy resources [75]. Higher amounts of degradation of energy inside the economic and environmental development performance of countries might cause larger environmental impacts affecting societies at local, regional or global levels [30].

\subsection{Linear Correlations, Empirical Evidence}

Many factors may have an impact in $\mathrm{CO}_{2}$ emissions; in this study were examined four major contributors: energy consumption, exergy consumption, exergy intensity and GDP. Prior to the econometric analysis, the prearrangement of the database was based on two criteria: by year, by country and vice versa. In addition, the averages of the values per year for each variable were computed. Last, an analysis of the data applying the linear regression method to obtain the determination coefficients was applied. Table 4 shows the results of the correlation factors $(R)$ between the different variables. As a result, $\mathrm{ffCO}_{2}(R \geq 0.95)$ emissions correlations get bigger coefficients compared to those of $\mathrm{pcCO}_{2}$ emissions $(R \geq 0.7)$ in terms of the control variables. Even when the present study do not consider individual test for countries, however compared with previous studies, in terms of statistical increases our results are similar for those of Alam [76], regarding the $\mathrm{CO}_{2}$ emissions and energy consumption by Brazil and China.

After the first test with a set of 44 observations per variable, yearly averages per country for each was computed, proceeding to estimate the correlations based on the $\mathrm{pcCO}_{2}$ as environmental deterioration; as a result, only three of them presented values of $R \geq 0.95$ (pcTPES, ffEx cons, Tr opn). It is remarkable that Ex int shows negative but high values of $R \geq 0.90$, explaining a linear but inverse or decreasing curve.

Table 4. Correlation coefficients matrix.

\begin{tabular}{|c|c|c|c|c|c|c|c|c|}
\hline & $\begin{array}{c}\text { pcGDP } \\
\text { (USD 2005) }\end{array}$ & $\underset{\left(\mathrm{MtonCO}_{2}\right)}{\mathrm{pcCO}_{2}}$ & $\mathrm{ffCO}_{2}$ & $\begin{array}{c}\text { ffEn Cons } \\
\text { (PJ) }\end{array}$ & $\begin{array}{c}\text { En int } \\
\text { (TPES/GDP) }\end{array}$ & $\begin{array}{c}\text { Ex int } \\
\text { (TPES/GDP) }\end{array}$ & $\begin{array}{l}\text { pcTPES } \\
\text { (TPES/GDP) }\end{array}$ & $\begin{array}{c}\text { Tr opn } \\
(\%)\end{array}$ \\
\hline pcGDP & 1 & - & - & - & - & - & - & - \\
\hline $\mathrm{ffCO}_{2}$ & 0.938 & 0.633 & 1 & - & - & - & - & - \\
\hline $\begin{array}{l}\text { ffEx } \\
\text { con }\end{array}$ & 0.956 & 0.624 & 0.998 & 1.000 & 1 & - & - & - \\
\hline pcTPES & 0.958 & 0.725 & 0.845 & 0.871 & 0.871 & -0.927 & 1 & - \\
\hline Tr opn & 0.949 & 0.624 & 0.989 & 0.990 & 0.990 & -0.934 & 0.861 & 1 \\
\hline
\end{tabular}

In economy, energy intensity is viewed as an indicator of the energy efficiency of an economy. It is calculated as the ratio between the energy consumption (En cons) and the gross domestic product (GDP) of a country, meaning the units of energy needed to produce a unit of economic growth [77]. The dataset of the panel shows that energy intensity countries with high values are the 5 developed ones; contrarily the 5 developing countries shows lower values, except by China with the higher of all of them but with a drastically decreasing trend. A deeper analysis in the datasets reveals that both energy and exergy intensities increased for developed countries plus China; but regrettably decrease in developing countries, pointing out opportunities to increase future efficiencies, and exergy efficiency is a fitted tool regarding the industrial sector $[44,62,78]$.

In fact, Energy efficiency is one of the main variables that induce a reduction in fossil-based energy consumption. In a study conducted by the International Energy Agency [79] shows that without the 
improvements made on energy efficiency during the period from 1973 to 2005 at global scale, the use of energy would have been $58 \%$ higher than the level recorded in 2005, highlighting the relevance of energy efficiency to reduce the energy request. However, since 1990, the energy efficiency rate has stagnated due to the lower economic interest affected by the relatively low price of fuels inducing an increase in the demand for oil [80]. Considering the energy efficiency as a control variable (reciprocal of energy intensity), the results showed that his trend could be negative but statistically significant $(R=0.95)$.

\subsection{Econometric Analysis of Empirical Results}

Several authors developed a literature survey on the nexus $\mathrm{CO}_{2}$-energy-growth and the $\mathrm{EKC}$, those overviews reveals similitudes with our work in terms of time frame and some of the selected countries, however, once our empirical test were based on average values by country and year, then $y$ it was not possible to study countries solely as it was not the goal of this work $[20,23,27,81]$. It is important to understand the relation between renewable and non-renewable energy consumption, $\mathrm{CO}_{2}$ emissions and economic growth in terms of revealing the dependence of the economy on energy and designing the energy policies [82]. Table 5 displays the results of the variables used in the analyses of the EKC; it is observed that there is a large dispersion between cross-section units (countries), mainly in the levels of per capita income.

The linear correlation result shows a positive trend between $\mathrm{ffCO}_{2}$ vs. $\mathrm{pcGDP}, \mathrm{ffCO}_{2}$ vs. Ex con and $\mathrm{ffCO}_{2}$ vs. Tr opn; as well as an inverted correlation of $\mathrm{ffCO}_{2}$ vs. Ex int. This relation depicts the existence of the EKC for the panel, with a feedback hypothesis. Afterwards, regarding the test of the hypothesis cited by Apergis et al. [83], in the present research work was detected that the pcGDP-exergy consumption relation confirms the growth hypothesis, similar to those results from Lee [84] by developing countries. These findings are in line with Magazzino et al. [85] once energy consumption tends to be more responsive to economic growth in less developed than in advanced countries; however it is important to state that according to them, the relationship between energy and economic growth activity could be affected by a variety of other factors. In addition to this, an ordinary least squares analysis (OLS) was developed to test the significance of the model; the results are presented in Table 6.

Table 5. Summary of empiric results of the multivariable framework.

\begin{tabular}{cccccccc}
\hline \multicolumn{7}{c}{ Variables } \\
& $\begin{array}{c}\text { pcGDP } \\
\text { (USD 2005) }\end{array}$ & $\begin{array}{c}\text { pcCO }_{2} \\
\text { (MtonCO2/Cap) }\end{array}$ & $\begin{array}{c}\text { ffEn Cons } \\
\text { (PJ) }\end{array}$ & $\begin{array}{c}\text { ffEx Con } \\
\text { (PJ) }\end{array}$ & $\begin{array}{c}\text { Ex int } \\
\text { (TPES/GDP) }\end{array}$ & $\begin{array}{c}\text { pcTPES } \\
\text { (toe/Cap) }\end{array}$ & $\begin{array}{c}\text { Tr opn } \\
\text { (\%) }\end{array}$ \\
\hline Media & $23,309.5$ & 7.5 & $17,814.3$ & $21,199.1$ & 117.8 & 3.4 & 64.7 \\
Median & $14,843.8$ & 6.6 & 6748.0 & 8030.1 & 117.7 & 2.6 & 48.6 \\
Stdr Dev & $21,027.3$ & 5.7 & $28,038.4$ & $33,365.7$ & 28.0 & 2.5 & 70.5 \\
Max & $91,597.2$ & 22.1 & $128,356.8$ & $152,744.6$ & 230.5 & 8.5 & 442.6 \\
Min & 262.9 & 0.9 & 557.9 & 664.0 & 44.3 & 0.5 & 9.1 \\
\hline
\end{tabular}

Table 6. Regression of $\mathrm{ffCO}_{2}$ emissions and pcGDP.

\begin{tabular}{cc}
\hline Variable & Coefficient \\
\hline Correlation coefficient $R^{2}-$ & 0.98260592 \\
Determination coefficient $R^{2}-$ & 0.96551439 \\
Adjusted $R^{2}-$ & 0.95992213 \\
Standard error & 0.0637957 \\
Observations & 44 \\
Countries & 10 \\
\hline
\end{tabular}

The independent variables pcGDP, Ex con, Ex int, pcTPES and Tr opn explain $96.55 \%$ of the variation of $\mathrm{ffCO}_{2}$. Besides, an analysis to test the global significance of the proposed model was 
developed, confirming its own validity. The overall effects of the model are significant since the null hypothesis is rejected due a low $p$-value $\leq 0.001$. Table 7 shows the long run tests results.

Table 7. Regression of $\mathrm{ffCO}_{2}$ emissions and pcGDP.

\begin{tabular}{ccccccc}
\hline & Coefficient & Stdr. Error & $\boldsymbol{t}$-Statistic & Probability & Inferior 95\% & Superior 95\% \\
\hline Interception & -7.843 & 0.787 & -9.968 & 0.000 & -9.440 & -6.250 \\
pcGDP & 0.000 & 0.000 & 3.168 & 0.003 & 0.000 & 0.000 \\
Ex con & 0.000 & 0.000 & -1.688 & 0.100 & 0.000 & 0.000 \\
Ex int & 0.037 & 0.010 & 3.813 & 0.001 & 0.020 & 0.060 \\
pcTPES & 0.961 & 0.257 & 3.735 & 0.001 & 0.440 & 1.480 \\
Tr opn & 0.005 & 0.005 & 1.008 & 0.320 & -0.010 & 0.020 \\
\hline
\end{tabular}

Thus, it was observed that the forecaster variables pcGDP, Ex int and pcTPES are statistically significant because their $p$-values are low $(<0.05)$. However, the $p$-value for $\operatorname{Tr}$ opn $(0.320)$ and Ex int (0.001) is greater than the common alpha level of 0.050, and an indication of statistically insignificant variables. Trade openness was also found statistically insignificant to Canada by Olale [86]. In comparison with past studies, the statistical insignificance of trade openness is different from those who find the variable negatively related to per capita $\mathrm{CO}_{2}$ emissions, especially in higher income countries [87]. Accordingly, Shahbaz found trade openness improves environmental quality, and Jebli claims that if it is combined with renewable energies, are efficient strategies to combat global warming. The growth of $\mathrm{ffCO}_{2}$ emissions and pcGDP in the first part of the curve is validated, since the increase in economic growth goes simultaneously with the degradation of the environment. Once it is observed that the sign of the quadratic term is positive, this implies that in a second stage, when the pcGDP remains increasing, it also grows the carbon dioxide emissions, non-validating the second part of the environmental curve. This result could be expected due the comparison of the mixed sample of developed and developing economies. Our finding is in accordance with what Kaika established, since the developed countries have shown evidence of the EKC, contrary to the developing countries $[28,29]$. As an example, causality running from energy consumption to GDP, or the evidence in the existence of the EKC are more valid in the developed countries compared with the developing ones [88]. Usually in developed countries, growth or feedback hypothesis is reported, and the curve changes its slope to negative for the reduction of emissions, considering that the country reached a level of economic stability where the degradation of the environment tends to decrease, making intensive use of green technologies [89]. On the contrary, developing economies, particularly China, the $\mathrm{CO}_{2}$ curve trend tend to remain increasing along the chosen timeline, as a consequence a growth hypothesis is suggested [90,91].

These results are in accordance with previous authors, due the influence of several external factors producing ups and downs trends in the curves [23,92]. Also interesting is the correlation between $\mathrm{pcCO}_{2}$ and exergy consumption, it shows a negative trend, describing possibly an inverted $N$ shape. This result opens the door to future research with the use of exergetic indicators, with the possibility to link exergy efficiencies and the use of renewables in countries [48]. Hence, detection of degradation of energy through exergy indicators is becoming a prominent topic in energy and environmental literature $[47,50,51,75]$. Energy analysis has been widely used by the academics and government agencies. Among others, Hammond [78,93] has argued that it is important for practitioners and policy makers to employ exergy analysis as a complement to the existing methods to develop datasets, official reports and environmental and energetic strategies. It is necessary to increase the contribution of exergy to the environment. Although this is a small sample of panel model of countries, the results of our study extend the debate of previous research in the use of the timeline, set of chosen countries, control variables or other external factors i.e., technology, socio political issues. According with the critical literature review studies, based on the overall empirical evidence controversy still surrounding the EKC hypothesis. The main issue comes up to be how the income-pollution relationship evolves when the EKC-concept ceases to be valid. Previous studies 
show that developing countries are expected to behave different than developed countries since socioeconomic-political unique conditions change over time [29]. Policy makers are therefore to exercise caution in their efforts to promote economic growth and at the same time reduce environmental degradation keeping in mind the sustainability of both the economy and the environment [76].

\section{Conclusions}

Series data from the period 1971-2014 for ten countries were analyzed in a comparative empirical study of selected developed and developing countries. In the whole period of 44 years, neutrality hypothesis was confirmed by OECD countries such as Canada, Mexico, Norway, Turkey, the UK and the USA. It means that there is no causality amid economic growth and energy consumption. Comparing the long run correlations between $\mathrm{CO}_{2}$ emissions from fossil fuels, GDP per capita and exergy consumption, a positive correlation trend was observed, denotes that by improving energy efficiency policies and regulatory instruments, the efficiency of the system under study tends to improve, accordingly decrease emissions and environmental impacts. The EKC was not confirmed, therefore, the efforts to reduce the GHGs emissions like Kyoto Protocol proves insufficient, as permanent patterns for reducing $\mathrm{CO}_{2}$ emission is not observed for the afore mentioned countries.

The results confirm the existence of strong correlations between the multivariable frameworks, excepted by the carbon intensity. Additionally, a long-term feedback hypothesis among $\mathrm{CO}_{2}$ emissions from fossil fuels, GDP per capita and exergy consumption was confirmed. Furthermore, and inverted-strong correlation between $\mathrm{CO}_{2}$ emissions from fossil fuels and exergy intensity are detected, offering and insight for future efficiency improvements. Finally, results from developed countries have been increased their effectiveness to manage environmental problems, especially, $\mathrm{CO}_{2}$ emissions.

Similar to previous research, the use of renewables or natural gas seems to be the right way to combat global warming and reduce $\mathrm{CO}_{2}$ emissions, enabling the reduction of energy dependency and promoting energy security. It is remarkable that restrictions on the use of energy can negatively affect economic growth, while increases in energy can contribute to economic growth. Consequently, it is concluded that energy is a limiting factor for economic growth and, therefore, the impacts on energy supply will have a negative impact on economic growth.

Regardless results do not support the EKC hypothesis, however exergy intensity opens the door for future research once it proves to be a useful control variable. Exergy provides opportunities to analyze and implement energy and environmental policies in these countries, once is a tool to minimize environmental harm, with the possibility to link exergy efficiencies and the use of renewables.

Future research should be focus on expanding the model and digging into its complexity, thus the inclusion of exergetic variables. Another venue could be focused to develop a deeper analysis at regional or country scale, regarding the correlations of environmental and exergetic indicators. As a final point, one of the main limitations to our study is the availability of the data, mainly in years before 1970 and specifically for developing countries. This problem should be overcome through the help of international organizations and institutions.

Author Contributions: Conceptualization and methodology design: R.A.-M., R.H. and R.R.-L. Experiments: R.A.-M. and S.P.I.-Z. Data analysis and validation: R.A.-M., R.R.-L. and S.P.I.-Z. Writing-Original Draft Preparation: R.A.-M., R.H. and R.R.-L. Writing-Review \& Editing: R.H., R.R.-L. and M.G. Supervision: R.H., R.R.-L. and M.G.

Funding: This research received no external founding.

Acknowledgments: The authors thanks to the great support provided by the Consejo Nacional de Ciencia y Tecnología (CONACYT) and from the Consejo Veracruzano de Investigación Científica y Desarrollo Tecnológico (COVEICYDET) through Ph.D. scholarship (No. 218934) to Raul Arango-Miranda.

Conflicts of Interest: The authors declare no conflict of interest. 


\section{Nomenclature}

EKC
$\mathrm{CO}_{2}$
$\mathrm{GDP}$
$\mathrm{pcCO}_{2}$
$\mathrm{ffCO}_{2}$
$\mathrm{pcTPES}$
pcGDP
Tr opn
ffEn con
En int
$\mathrm{C}$ int
Ex con
Exint
Exergysys
Exergy
Exergy
Exergy
Pt
Exergy
Ef
$\gamma f$
$H H V f$
ED
EG
EnC
ExC

EKC

GDP

$\mathrm{pcCO}_{2}$

$\mathrm{ffCO}_{2}$

pcTPES

pcGDP

ffEn con

En in

Excon

Ex int

Exergy ${ }^{P h}$

Exergy ${ }^{K n}$

Exergy ${ }^{P t}$

Exergy ${ }^{C h}$

$\gamma f$

$H H V f$

EG

$E x C$
Environmental Kuznets Curve

Carbon dioxide emissions

Gross domestic product

Carbon dioxide emissions per capita

Carbon dioxide Emissions from fossil fuels

Total Primary Energy Supply per capita

Gross Domestic Product (GDP) per capita; USD 2005

Trade openness

Energy consumption from fossil fuels

Energy Intensity

Carbon intensity

Exergy Consumption

Exergy Intensity

Exergy of the system under study

Physical exergy of the system under study

Kinetic exergy of the system under study

Potential exergy of the system under study

Chemical exergy of the system under study

Exergy of fuels

Exergy grade function.

High heating value of fuels

Environmental degradation

Economic growth

Energy consumption

Exergy consumption

\section{References}

1. Lorek, S.; Spangenberg, J.H. Sustainable consumption within a sustainable economy-beyond green growth and green economies. J. Clean. Prod. 2014, 63, 33-44. [CrossRef]

2. Hanif, I. Economics-energy-environment nexus in latin america and the caribbean. Energy 2017, 141, 170-178. [CrossRef]

3. To, W.-M.; Lee, P.K.C. Energy consumption and economic development in Hong Kong, China. Energies 2017, 10, 1883. [CrossRef]

4. Urban, F.; Nordensvärd, J. Low carbon energy transitions in the nordic countries: Evidence from the environmental kuznets curve. Energies 2018, 11, 2209. [CrossRef]

5. Arrow, K.; Bolin, B.; Costanza, R.; Dasgupta, P.; Folke, C.; Holling, C.S.; Jansson, B.-O.; Levin, S.; Mäler, K.-G.; Perrings, C. Economic growth, carrying capacity, and the environment. Science 1995, 268, 520-521. [CrossRef] [PubMed]

6. Hu, Y.; Guo, D.; Wang, M.; Zhang, X.; Wang, S. The relationship between energy consumption and economic growth: Evidence from china's industrial sectors. Energies 2015, 8, 9392-9406. [CrossRef]

7. UNEP; IPCC. Climate Change 2014, Report. Mitigation on Climate Change. Available online: http://www. ipcc.ch/report/ar5/wg3/ (accessed on 30 May 2018).

8. Government of Canada. Global Greenhouse Gas Emissions. Available online: https:/ / www.canada.ca/en/ environment-climate-change/services/environmental-indicators/global-greenhouse-gas-emissions.html (accessed on 7 May 2018).

9. Vlontzos, G.; Niavis, S.; Pardalos, P. Testing for environmental kuznets curve in the eu agricultural sector through an eco-(in) efficiency index. Energies 2017, 10, 1992. [CrossRef]

10. Robinson, J. Squaring the circle? Some thoughts on the idea of sustainable development. Ecol. Econ. 2004, 48, 369-384. [CrossRef]

11. Turki, S.; Sauvey, C.; Rezg, N. Modelling and optimization of a manufacturing/remanufacturing system with storage facility under carbon cap and trade policy. J. Clean. Prod. 2018, 193, 441-458. [CrossRef] 
12. Sariannidis, N.; Zafeiriou, E.; Giannarakis, G.; Arabatzis, G. $\mathrm{CO}_{2}$ emissions and financial performance of socially responsible firms: An empirical survey. Bus. Strategy Environ. 2013, 22, 109-120. [CrossRef]

13. Munasinghe, M.; Cutler, J. Sustainable development triangle. Encycl. Earth 2017.

14. Ponta, L.; Raberto, M.; Teglio, A.; Cincotti, S. An agent-based stock-flow consistent model of the sustainable transition in the energy sector. Ecol. Econ. 2018, 145, 274-300. [CrossRef]

15. Wolf, S.; Schütze, F.; Jaeger, C. Balance or synergies between environment and economy-A note on model structures. Sustainability 2016, 8, 761. [CrossRef]

16. Fodha, M.; Zaghdoud, O. Economic growth and pollutant emissions in tunisia: An empirical analysis of the environmental kuznets curve. Energy Policy 2010, 38, 1150-1156. [CrossRef]

17. Bekhet, H.A.; Matar, A.; Yasmin, T. $\mathrm{CO}_{2}$ emissions, energy consumption, economic growth, and financial development in gcc countries: Dynamic simultaneous equation models. Renew. Sustain. Energy Rev. 2017, 70, 117-132. [CrossRef]

18. Kraft, J.; Kraft, A. On the relationship between energy and GNP. J. Energy Dev. 1978, 3, 401-403.

19. Stern, D.I. The rise and fall of the environmental kuznets curve. World Dev. 2004, 32, 1419-1439. [CrossRef]

20. Moutinho, V.; Varum, C.; Madaleno, M. How economic growth affects emissions? An investigation of the environmental kuznets curve in portuguese and spanish economic activity sectors. Energy Policy 2017, 106, 326-344. [CrossRef]

21. Grossman, G.M.; Krueger, A.B. Economic growth and the environment. Q. J. Econ. 1995, 110, $353-377$. [CrossRef]

22. Dinda, S. Environmental kuznets curve hypothesis: A survey. Ecol. Econ. 2004, 49, 431-455. [CrossRef]

23. Ozturk, I. A literature survey on energy-growth nexus. Energy Policy 2010, 38, 340-349. [CrossRef]

24. Bo, S. A literature survey on environmental kuznets curve. Energy Procedia 2011, 5, 1322-1325. [CrossRef]

25. Rahman, M.M.; Kashem, M.A. Carbon emissions, energy consumption and industrial growth in bangladesh: Empirical evidence from ardl cointegration and granger causality analysis. Energy Policy 2017, 110, 600-608. [CrossRef]

26. Chowdhury, R.R.; Moran, E.F. Turning the curve: A critical review of kuznets approaches. Appl. Geogr. 2012, 32, 3-11. [CrossRef]

27. Stern, D.I. The environmental kuznets curve after 25 years. J. Bioecon. 2017, 19, 7-28. [CrossRef]

28. Kaika, D.; Zervas, E. The environmental kuznets curve (EKC) theory-Part A: Concept, causes and the $\mathrm{CO}_{2}$ emissions case. Energy Policy 2013, 62, 1392-1402. [CrossRef]

29. Kaika, D.; Zervas, E. The environmental kuznets curve (EKC) theory. Part B: Critical issues. Energy Policy 2013, 62, 1403-1411. [CrossRef]

30. Rosen, M.A.; Dincer, I. Exergy as the confluence of energy, environment and sustainable development. Exergy Int. J. 2001, 1, 3-13. [CrossRef]

31. Loiseau, E.; Junqua, G.; Roux, P.; Bellon-Maurel, V. Environmental assessment of a territory: An overview of existing tools and methods. J. Environ. Manag. 2012, 112, 213-225. [CrossRef] [PubMed]

32. Vega-Azamar, R.E.; Romero-López, R.; Glaus, M.; Oropeza-García, N.A.; Hausler, R. Sustainability assessment of the residential land use in seven boroughs of the island of Montreal, Canada. Sustainability 2015, 7, 2454-2472. [CrossRef]

33. Sciubba, E.; Ulgiati, S. Emergy and exergy analyses: Complementary methods or irreducible ideological options? Energy 2005, 30, 1953-1988. [CrossRef]

34. Geng, Y.; Zhang, P.; Ulgiati, S.; Sarkis, J. Emergy analysis of an industrial park: The case of Dalian, China. Sci. Total Environ. 2010, 408, 5273-5283. [CrossRef] [PubMed]

35. Sciubba, E.; Wall, G. A brief commented history of exergy from the beginnings to 2004. Int. J. Thermodyn. 2007, 10, 1-26.

36. Reistad, G. Available energy conversion and utilization in the United States. J. Eng. Power 1975, 97, 429-434. [CrossRef]

37. Wall, G. Exergy-a Useful Concept within Resource Accounting; Chalmers Tekniska Högskola, Göteborgs Universitet: Göteborg, Sweden, 1977.

38. Szargut, J.; Morris, D.R.; Steward, F.R. Exergy Analysis of Thermal, Chemical, and Metallurgical Processes; Hemisphere Publishing: New York, NY, USA, 1987. 
39. Lozano, M.; Valero, A. Application of the exergetic costs theory to a steam boiler in a thermal generating station. ASME Book 1987, 41-51.

40. Sciubba, E.; Bastianoni, S.; Tiezzi, E. Exergy and extended exergy accounting of very large complex systems with an application to the province of Siena, Italy. J. Environ. Manag. 2008, 86, 372-382. [CrossRef] [PubMed]

41. Ayres, R.U.; Ayres, L.W.; Warr, B. Exergy, power and work in the US economy, 1900-1998. Energy 2003, 28, 219-273. [CrossRef]

42. Wall, G. Exergy conversions in the Finnish, Japanese and Swedish societies. OPUSCULA Exergy Pap. 1991, 1-11.

43. Ertesvåg, I.S. Society exergy analysis: A comparison of different societies. Energy 2001, 26, $253-270$. [CrossRef]

44. Rosen, M.A. Evaluation of energy utilization efficiency in canada using energy and exergy analyses. Energy 1992, 17, 339-350. [CrossRef]

45. Dincer, I.; Rosen, M.A. Exergy; Elsevier: Amsterdam, The Netherlands, 2013; pp. 537-552.

46. BoroumandJazi, G.; Rismanchi, B.; Saidur, R. A review on exergy analysis of industrial sector. Renew. Sustain. Energy Rev. 2013, 27, 198-203. [CrossRef]

47. Romero, J.C.; Linares, P. Exergy as a global energy sustainability indicator. A review of the state of the art. Renew. Sustain. Energy Rev. 2014, 33, 427-442. [CrossRef]

48. Gong, M.; Wall, G. Exergy analysis of the supply of energy and material resources in the Swedish society. Energies 2016, 9, 707. [CrossRef]

49. Utlu, Z.; Hepbasli, A. A review and assessment of the energy utilization efficiency in the Turkish industrial sector using energy and exergy analysis method. Renew. Sustain. Energy Rev. 2007, 11, 1438-1459. [CrossRef]

50. Rosen, M.A.; Dincer, I. On exergy and environmental impact. Int. J. Energy Res. 1997, 21, 643-654. [CrossRef]

51. Dincer, I.; Rosen, M.A. Exergy as a driver for achieving sustainability. Int. J. Green Energy 2004, 1, 1-19. [CrossRef]

52. IEA. Energy Balances; International Energy Agency (IEA): Paris, France, 2017.

53. IEA. $\mathrm{CO}_{2}$ Emissions from Fuel Combustion, Statistics 2017. Highligths; International Energy Agency (IEA): Paris, France, 2017; p. 162.

54. World Bank. World Development Indicators 2014; World Bank Publications: Washington, DC, USA, 2014.

55. Magazzino, C. A panel var approach of the relationship among economic growth, $\mathrm{CO}_{2}$ emissions, and energy use in the asean-6 countries. SSRN 2014, 4, 546-553.

56. Nejat, P.; Jomehzadeh, F.; Taheri, M.M.; Gohari, M.; Abd. Majid, M.Z. A global review of energy consumption, $\mathrm{CO}_{2}$ emissions and policy in the residential sector (with an overview of the top ten $\mathrm{CO}_{2}$ emitting countries). Renew. Sustain. Energy Rev. 2015, 43, 843-862. [CrossRef]

57. Burck, J.; Marten, F.; Bals, C.; Höhne, N. The Climate Change Performance Index: Results 2015; Germanwatch: Berlin, Germany, 2014; p. 32.

58. Wall, G.; Sciubba, E.; Naso, V. Exergy use in the Italian society. Energy 1994, 19, 1267-1274. [CrossRef]

59. Dincer, I. Sectoral energy and exergy modeling of Turkey. J. Energy Resour. Technol. 1997, 119, $200-204$.

60. Rosen, M.A. Using exergy to assess regional and national energy utilization: A comparative review. Arab. J. Sci. Eng. 2013, 38, 251-261. [CrossRef]

61. Al-Ghandoor, A.; Phelan, P.E.; Villalobos, R.; Jaber, J.O. Energy and exergy utilizations of the U.S. Manufacturing sector. Energy 2010, 35, 3048-3065. [CrossRef]

62. Utlu, Z.; Hepbasli, A. A review on analyzing and evaluating the energy utilization efficiency of countries. Renew. Sustain. Energy Rev. 2007, 11,1-29. [CrossRef]

63. Guevara, Z.; Sousa, T.; Domingos, T. Insights on energy transitions in mexico from the analysis of useful exergy 1971-2009. Energies 2016, 9, 488.

64. Bühler, F.; Nguyen, T.-V.; Elmegaard, B. Energy and exergy analyses of the danish industry sector. Appl. Energy 2016, 184, 1447-1459. [CrossRef]

65. International Energy Agency (IEA). Statistics. Statistics Search. Available online: https://www.iea.org/ statistics/statisticssearch/ (accessed on 25 May 2018).

66. Zilio, M.; Recalde, M. GDP and environment pressure: The role of energy in Latin America and the Caribbean. Energy Policy 2011, 39, 7941-7949. [CrossRef] 
67. Shahbaz, M.; Loganathan, N.; Zeshan, M.; Zaman, K. Does renewable energy consumption add in economic growth? An application of auto-regressive distributed lag model in Pakistan. Renew. Sustain. Energy Rev. 2015, 44, 576-585. [CrossRef]

68. De Bruyn, S.M. Explaining the environmental kuznets curve: Structural change and international agreements in reducing sulphur emissions. Environ. Dev. Econ. 1997, 2, 485-503. [CrossRef]

69. Panayotou, T. Demystifying the environmental kuznets curve: Turning a black box into a policy tool. Environ. Dev. Econ. 1997, 2, 465-484. [CrossRef]

70. Shahbaz, M.; Kumar Tiwari, A.; Nasir, M. The effects of financial development, economic growth, coal consumption and trade openness on $\mathrm{CO}_{2}$ emissions in South Africa. Energy Policy 2013, 61, 1452-1459. [CrossRef]

71. IEA. $\mathrm{CO}_{2}$ emissions from fuel combustion, statistics 2017. Highligths; International Energy Agency (IEA): Paris, France, 2017; p. 162.

72. IEA. IEA Worldwide Trends in Energy Use and Efficiency: Key Insights from Iea Indicator Analysis; International Energy Agency (IEA): Paris, France, 2008; p. 94.

73. Pereira, M.G.; Freitas, M.A.V.; da Silva, N.F. The challenge of energy poverty: Brazilian case study. Energy Policy 2011, 39, 167-175. [CrossRef]

74. Hepbasli, A. A key review on exergetic analysis and assessment of renewable energy resources for a sustainable future. Renew. Sustain. Energy Rev. 2008, 12, 593-661. [CrossRef]

75. Dincer, I. The role of exergy in energy policy making. Energy Policy 2002, 30, 137-149. [CrossRef]

76. Alam, M.M.; Murad, M.W.; Noman, A.H.M.; Ozturk, I. Relationships among carbon emissions, economic growth, energy consumption and population growth: Testing environmental kuznets curve hypothesis for Brazil, China, India and Indonesia. Ecol. Indic. 2016, 70, 466-479. [CrossRef]

77. Ang, B.W. Monitoring changes in economy-wide energy efficiency: From energy-GDP ratio to composite efficiency index. Energy Policy 2006, 34, 574-582. [CrossRef]

78. Arango-Miranda, R.; Hausler, R.; Romero-López, R.; Glaus, M.; Ibarra-Zavaleta, S.P. An overview of energy and exergy analysis to the industrial sector, a contribution to sustainability. Sustainability 2018, 10, 153. [CrossRef]

79. IEA. Energy Efficiency; Market Report 2015; Internacional Energy Agency (IEA): Paris, France, 2015 ; p. 250.

80. Proskuryakova, L.; Kovalev, A. Measuring energy efficiency: Is energy intensity a good evidence base? Appl. Energy 2015, 138, 450-459. [CrossRef]

81. Pasten, R.; Figueroa, E. The environmental kuznets curve: A survey of the theoretical literature. Int. Rev. Environ. Resour. Econ. 2012, 6, 195-224. [CrossRef]

82. Khobai, H.; Le Roux, P. Does renewable energy consumption drive economic growth: Evidence from granger-causality technique. Int. J. Energy Econ. Policy 2018, 8, 205-212.

83. Apergis, N.; Payne, J.E. Energy consumption and economic growth: Evidence from the commonwealth of independent states. Energy Econ. 2009, 31, 641-647. [CrossRef]

84. Lee, C.-C. Energy consumption and GDP in developing countries: A cointegrated panel analysis. Energy Econ. 2005, 27, 415-427. [CrossRef]

85. Magazzino, C. Energy consumption and aggregate income in Italy: Cointegration and causality analysis. MPRA. 2011. Available online: https://mpra.ub.uni-muenchen.de/28494/ (accessed on 19 September 2018).

86. Olale, E.; Ochuodho, T.O.; Lantz, V.; El Armali, J. The environmental kuznets curve model for greenhouse gas emissions in Canada. J. Clean. Prod. 2018, 184, 859-868. [CrossRef]

87. Ben Jebli, M.; Ben Youssef, S.; Ozturk, I. Testing environmental kuznets curve hypothesis: The role of renewable and non-renewable energy consumption and trade in OECD Countries. Ecol. Indic. 2016, 60, 824-831. [CrossRef]

88. Chontanawat, J.; Hunt, L.C.; Pierse, R. Does energy consumption cause economic growth? Evidence from a systematic study of over 100 countries. J. Policy Model. 2008, 30, 209-220. [CrossRef]

89. Lee, C.-C.; Chang, C.-P.; Chen, P.-F. Energy-income causality in OECD Countries revisited: The key role of capital stock. Energy Econ. 2008, 30, 2359-2373. [CrossRef]

90. Fang, Y. Economic welfare impacts from renewable energy consumption: The China experience. Renew. Sustain. Energy Rev. 2011, 15, 5120-5128. [CrossRef] 
91. Zhang, X.-P.; Cheng, X.-M. Energy consumption, carbon emissions, and economic growth in china. Ecol. Econ. 2009, 68, 2706-2712. [CrossRef]

92. Özokcu, S.; Özdemir, Ö. Economic growth, energy, and environmental kuznets curve. Renew. Sustain. Energy Rev. 2017, 72, 639-647. [CrossRef]

93. Hammond, G.; Stapleton, A. Exergy analysis of the United Kingdom energy system. Proc. Inst. Mech. Eng. Part A J. Power Energy 2001, 215, 141-162. [CrossRef] 